\author{
Mariola Walczak-Mikołajczakowa \\ UAM \\ mawal@amu.edu.pl
}

Data przesłania tekstu do redakcji: 16.07 .2014

Data przyjęcia tekstu do druku: 22.08.2014

\title{
Bułgarzy banaccy - fenomen trwałości kultury
}

\begin{abstract}
Walczak-Mikołajczakowa Mariola, Bułgarzy banaccy-fenomen trwałości kultury (The Banat Bulgarians - a Phenomenon of Cultural Continuity). „Poznańskie Studia Slawistyczne” 8. Poznań 2015. Publishing House of the Poznań Society for the Advancement of the Arts and Sciences, pp. 229-237. ISSN 2084-3011.

Nowadays, the so-called Banat Bulgarians are a numerous group of the descendants of Bulgarian Catholics, which were forced to emigrate to Wallachia in the end of the $17^{\text {th }}$ century and in the beginning of the $18^{\text {th }}$ century and from there in years $1738-1741$ to Banat. Small part of them (after 1878) returned to Bulgaria where they establish new villages. Most of them still live in Romanian territory, decidedly less numerous colonies are in Hungary and in Serbia. From the end of $19^{\text {th }}$ century they were a subject of interest to historians and linguists. For historians, their history were extremely interesting. For linguists, because they managed to salvage the dialect which became (in the half of the $19^{\text {th }}$ century) a base of literary norm that was to shape their language.
\end{abstract}

KEYwords: Catholicism; emigration; literary norm; cultural continuity

Literatura dotycząca Bułgarów banackich, czyli licznej grupy bułgarskich katolików, którzy na przełomie XVII i XVIII wieku zostali zmuszeni do emigracji na Wołoszczyznę, a stamtąd - w latach 1738-1741 - do Banatu, jest bardzo obszerna. Bułgarscy historycy i językoznawcy zainteresowali się nimi już pod koniec XIX wieku (Miletič 1896; 1897; 1900), a ich następcy kontynuowali badania przez cały wiek XX. Opublikowana w 1999 roku bibliografia prac poświęconych wprost lub pośrednio Bułgarom banackim obejmuje ponad 150 pozycji (Niagulov 1999: 333-347). Badania trwają także obecnie, czego dowodem może być realizowany w ostatnich latach z funduszy Unii Europejskiej wspólny projekt badawczy kilku uniwersytetów z Bułgarii, Rumunii, Serbii i Węgier. Z całą pewnością obecna bibliografia, po piętnastu latach od opublikowania poprzedniej, jest znacznie obszerniejsza (a zauważmy, że należałoby także 
uwzględnić poświęcone Bułgarom banackim strony internetowe, które już z pobieżnego oglądu wydają się bardzo liczne ${ }^{1}$ ).

Wciąż jednak sporna pozostaje liczebność tej grupy ludności. Najczęściej podaje się, że w momencie przesiedleń z katolickich ośrodków w Bułgarii wyemigrowało około pięciu tysięcy osób. Pierwsza grupa emigrantów pochodziła $\mathrm{z}$ położonego na prawym brzegu rzeki Ogosty (północno-zachodnia Bułgaria) miasta Čiprovci, skatolicyzowanego najprawdopodobniej już w XIV wieku za sprawą osadników z Saksonii. Miasto przeszło do historii przede wszystkim dzięki wznieconemu tam powstaniu antytureckiemu w 1688 roku. Pogrom ludności po upadku tego powstania spowodował, że - jak odnotował kronikarz bułgarskiej prowincji franciszkańskiej - z 500 rodzin cziprowskich, tylu samo z miejscowości Kopilovci oraz 300 z Železny i 80 z Klisury, przetrwała jedynie jedna trzecia (Летопис на Българската францисканска провинция: 35). Ocalała ludność (około 300 rodzin) zaczęła szukać schronienia na północ od Dunaju, osiedlając się początkowo w miejscowościach Krajova, Rimnik, Bradiceni i innych. Stamtąd, po spustoszeniu jej siedzib przez Tatarów w 1690 roku, grupa ta uciekła przez Karpaty do władanego przez Habsburgów Siedmiogrodu. W roku 1700 uchodźcy uzyskali od cesarza Leopolda I przywilej pozwalający im założyć własną kolonię w Alvinc, jednak po wybuchu powstania Rakoczego byli zmuszeni stamtąd uciekać jako wierni poddani Austrii. Stłumienie buntu w 1711 roku dało im możliwość odbudowy swoich kolonii w miejscowościach Alvinc i Deva. W tym samym czasie przybywali też nowi osadnicy, głównie tzw. północni paulicjanie z okolic Nikopola ${ }^{2}$, prześladowani przez Turków z powodu podejrzeń o szpiegostwo na rzecz Austrii i jednocześnie zachęcani przez Austrię licznymi przywilejami, nadaniami żyznej ziemi itp. (Walczak-Mikołajczakowa 2008: 222). Nie należy więc się dziwić, że w połowie XIX wieku różni autorzy podawali liczby osadników wahające

${ }^{1}$ Po wpisaniu do internetowej wyszukiwarki Google hasła Bułgarzy banaccy w języku polskim otrzymano 273 odpowiedzi (dostęp: 30.06.2014), po przejściu zaś do tej samej wyszukiwarki w języku bułgarskim i wpisaniu hasła cyrylicą - 185 tysięcy odpowiedzi (ta sama data dostępu).

${ }^{2}$ Terminem ,paulicjanie” określa się zwyczajowo bułgarskich katolików, gdyż w dużej części wywodzili się z rzesz dawnych wyznawców paulicjańskiej herezji manichejskiej. Bułgarzy banaccy zachowali zresztą tę nazwę i do dzisiaj sami mówią o sobie paulkieni. 
się między 22 a 26 tysiącami, kodyfikator ich języka, Josif (Józu) Rill, w roku zaś 1864 pisał nawet o 30-35 tysiącach i zaznaczał, że ich kolonie rozrastają się szybko z powodu niezwykle dużej dzietności rodzin (Kolev 2005: 199).

Dzisiaj Bułgarzy banaccy mieszkają przede wszystkim na obszarze Rumunii (udało im się stworzyć na tym terenie trwałe, zwarte kolonie największe $z$ nich to Bešenov i Vinga - tam też założyli swoje stowarzyszenie, szkoły z własnym językiem nauczania, wydawali czasopisma itp.). $\mathrm{Na}$ Węgrzech istnieje obecnie zaledwie osiem wsi w okolicach Szegedu, w których mieszkają Bułgarzy banaccy, w Serbii zaś (dokładniej w Wojwodinie) są bardziej rozproszeni i zasymilowani językowo oraz kulturowo, toteż trudno mówić o mikronarodzie bułgaro-banackim w tym kraju (o ile w ogóle można używać wobec Bułgarów banackich zaproponowanego przez redaktorów tomu określenia mikronaród!).

Największy rozkwit gospodarczy i kulturowy Bułgarów banackich nastąpił dzięki otrzymanym od władców Austrii przywilejom - udało im się nie tylko utworzyć swoje ośrodki w Banacie, ale także zachować tradycję i obyczajowość, a przede wszystkim specyficzny archaiczny dialekt, w którym powstała obfita twórczość ludowa o charakterze religijnym (Walczak-Mikołajczakowa 2010: 109-112; 2012: 149-158).

Po 1878 roku część Bułgarów banackich zdecydowała się na powrót do ojczystych stron. Reemigranci z Banatu założyli nowe wsie: Byrdarski Geran (region Beloslatina) i Dylbok Geran (region Plewen), ale później (1888 rok) niedostatek wody zmusił większość do opuszczenia tych osad i stworzenia nowych wsi. W ten sposób powstały: Asenovo (okr. Nikopol), Gostilia i Bergare (okr. Oriachovo), a także Machmudia, Vojvodovo i Dzhurovo (okr. Vraca). Jednak życie w żadnej z wymienionych wsi nie przebiegało podobnie - różny był bowiem sposób utrzymywania kontaktów i współżycia z prawosławnym otoczeniem. Zdaniem Angela Jankova, obecnie w Bułgarii istnieje tylko jedna wieś, którą możemy uznać za zamieszkałą wyłącznie przez Bułgarów banackich - jest to Byradarski Geran (Jankov 2003), toteż przytaczana przez źródła internetowe liczba reemigrantów szacowana na około sześć tysięcy wydaje się przesadzona. Współcześnie uznaje się, że żyje około 22 tysięcy Bułgarów banackich, choć tym danym przeczą oficjalne statystyki wszystkich zamieszkiwanych przez nich krajów. 
Niezależnie jednak od faktycznej liczebności Bułgarów banackich nie należy pomijać faktu, że stanowią oni swoisty fenomen kulturowy - grupę skonsolidowaną nie tyle przez pochodzenie etniczne (wszak w czasie ich emigracji pojęcie narodu i poczucie wspólnoty narodowej jeszcze na Bałkanach nie istniało), ile przede wszystkim przez wiarę katolicką, której wyznawanie już w Bułgarii czyniło z nich swoistą enklawę w prawosławnym otoczeniu. Istotny jest również tylko im właściwy język (dialekt) - posługiwali się nim (i nadal posługują), wyróżniając się tym samym spośród pozostałej ludności.

Język Bułgarów banackich kontynuuje tradycje dialektu paulicjańskiego, który, zdaniem największego bułgarskiego dialektologa Stojka Stojkova, należy sytuować wśród narzeczy południowo-wschodnich, a dokładniej środkoworupskich, czyli rodposkich (bułgarskie terminy naвликянско наречие і говор на северните павликяни oraz говор на южните павликяни funkcjonują od czasów badań zapoczątkowanych przez Lubomira Miletiča). Należący do gwar rodopskich dialekt paulicjański, ze względu na obecność pewnych cech archaicznych, reprezentuje starszą fazę rozwoju tych gwar, dodatkowo wykształciły się w nim pewne osobliwe cechy, spowodowane odizolowaniem od otoczenia ludności katolickiej (Stojkov 2002: 137; Walczak-Mikołajczakowa 2004: 149-159). Zestawienie najistotniejszych cech tego dialektu zostało opublikowane w języku polskim w innym miejscu (Walczak-Mikołajczakowa 2008: 225-227), zatem nie będzie ono tutaj przytaczane. Inny bułgarski dialektolog Maksim Mladenov dokonał bardziej szczegółowego przeglądu bułgarskich gwar na terenie Rumunii, uwzględniając w swoich analizach występowanie pewnych cech związanych z miejscem pochodzenia mieszkańców poszczególnych wsi, stosował zatem bogatszą nomenklaturę (Mladenov 1993: 60-317), w niniejszym artykule pozostaniemy jednak przy terminie ,język Bułgarów banackich", gdyż w XIX wieku został on znormalizowany, dokonała się jego intelektualizacja i kodyfikacja.

Fakt normalizacji języka Bułgarów banackich ma znaczenie nie do przecenienia, jest to bowiem druga (po oficjalnej, państwowej), a w zasadzie chronologicznie pierwsza, norma języka bułgarskiego, związana ściśle z katolickimi emigrantami żyjącymi na uchodźstwie. Próba normalizacji języka bułgarskich katolików została podjęta już pod koniec XVIII wieku przez najważniejszych pisarzy katolickich tamtego okresu: Pawła 
Duwanliję Gajdadżijskiego i Piotra Kowaczewa Carskiego. To w ich rękopiśmiennych, lecz często kopiowanych i rozpowszechnianych utworach został po raz pierwszy zastosowany alfabet łaciński oraz ortografia wzorowana na chorwackiej (bułgarscy duchowni to wychowankowie kolegium iliryjskiego w Loreto, a chorwacka literatura religijna, dystrybuowana przez kupców z Dubrownika, była wśród paulicjan niezwykle popularna). Tym samym w utworach obu wymienionych autorów zostały oddane wszystkie najważniejsze cechy dialektu paulicjańskiego, nie tylko fonetyczne, ale także leksykalne i składniowe, odróżniające język paulicjan od innych bułgarskich gwar (Walczak-Mikołajczakowa 2004). Ten język i tradycję piśmienniczą przenieśli katolicy bułgarscy do Banatu.

Jak wspominałam, inicjatorem i głównym twórcą kodyfikacji języka Bułgarów banackich był nauczyciel i działacz oświatowy Josif Rill. W roku 1866, za sprawą Stowarzyszenia Nauczycieli z Vingi, wydał pracę zatytułowaną Balgarskotu pravopisanj, napisaną w języku paulicjan z zastosowaniem chorwackiej redakcji pisma łacińskiego. Josif Rill przyjął w niej zasadę fonetyczną, czyli zapis wyrazów w takiej postaci, w jakiej się je wymawia. Wykorzystał do tego 33 literowe odpowiedniki głosek używanych w dialekcie paulicjanskim, spośród których na uwagę zasługują litery A, a (odpowiednik cyrylickiego b, ъ), Á, á (odpowiedniki A, a), Č, č (odpowiedniki Ч, ч), Ć, ć, wymawiane jak cyrylickie miękkie k' (Кь, кь), É, é (odpowiednik cyrylickiego ‘), Gj, gj (miękkie g', odpowiednik cyrylickiego Гь, гь), Lj, lj, (miękkie l', odpowiednik cyrylickiego Ль, ль), $\mathrm{Nj}$, nj (miękkie n', odpowiednik cyrylickiego Hь, нь) oraz Š, š (cyrylickie Ш, ш) i Ž, ž (cyrylickie Ж, ж).

Normę banacką wykorzystywano odtąd w literaturze religijnej, w Kościele, prasie i szkolnictwie. W latach 1860-1896 języka znormalizowanego przez Rilla nauczano w bułgarskich szkołach w Banacie (później został zastąpiony przez węgierski, a po 1918 roku także rumuński i serbski). Pozostał do dziś w użyciu domowym, na lekcjach religii oraz podczas nabożeństw. W tym miejscu zresztą należy podkreślić rolę Kościoła katolickiego jako czynnika spajającego omawianą społeczność i będącego gwarancją utrzymania języka (nawet przed II soborem watykańskim w Kościele używano łaciny i języka paulicjańskiego).

Wprowadzona przez Rilla norma okazała się trwała, powtórzył ją w niezmienionej postaci proboszcz parafii w Starym Beszenowie (Stár 
Bišnov), Ján Vasilčin, w aneksie do napisanego przez siebie i wydanego w 1991 roku katechizmu Biblija i Kátaćizmus za dicáta. Znajdujemy tam rozdział Nášta pismenus, w którym czytamy: „Taze Biblija i Kátaćizmus sa napisani na balgarsćija-palćensć jazić” (Vasilčin 1991: 71). Rozumiejąc, że potomkowie dawnych emigrantów żyjący w obcojęzycznym otoczeniu, uczęszczający do szkół z rumuńskim językiem nauczania, używają swojego języka rodzimego jedynie w domu, na lekcjach religii i podczas nabożeństw, banacki duchowny starał się im przybliżyć nie tylko kwestie religijne, ale zadbał też o pielęgnowanie języka, przybliżając młodym ortografię na podstawie przykładów (z których tylko niektóre zostaną tu przytoczone):

Spured či mlogjije redku pate se sreštet s tuje pisanj, po dole za dadémi sate sluvá i kaće se uputrebuvat.

A, a - alát, almár, aku; Aláta mi-j almáre (...).

Ć, ć - ćarmida, ćiša, ćika; Ćoravija u ćišata tripár ud stuć.

Dz, dz - dzonj, dzvezda, dzid; Dzidce gradi dzidve.

É, é - méne, pépelj, ždrébe; Pétar jadé méd.

Lj, lj - ljutna, ljubov, kljucka; Kaljváče kaljvé s klavnicata (Vasilčin 1991: 71).

Ta sama norma była stosowana w wydawanych przez Bułgarów banackich czasopismach i almanachach, w książkach o charakterze religijnym, zbiorach poezji i podręcznikach dla dzieci. Stosowali ją najznamienitsi przedstawiciele tej społeczności, tacy jak Ivan Fermendžin (urzędnik państwowy, który wznowił działalność wydawniczą Bułgarów banackich po 1918 roku), Anton Lebanov (autor utworów poetyckich, redagujący razem z Fermendžinem pismo „Našte Nedele. Vremenita nuvina na banastsćite balgare"), Karol Telbizov (wydawca i główny redaktor wychodzącego w latach 1935-1943 czasopisma „Banátsći balgarsći glasnić”, które pod swoim szyldem publikowało także różnego rodzaju książki banackich autorów) i inni. Znormalizowany przez Rilla język był przez lata i pozostaje nadal nie tylko czynnikiem wyróżniającym i spajającym banacką społeczność, pozwalającym jej zachować tożsamość nawet w najtrudniejszych czasach, ale także obiektem dumy.

Może właśnie dlatego tak wiele kontrowersji i dyskusji, toczących się także publicznie, na wielu stronach internetowych, wywołało wydanie w 2010 roku książki Буквар и Читанка autorstwa Ogniana Cvetkova i Augustyna Kalania, skierowanej przede wszystkim do dzieci reemigrantów, 
ale także tych, którzy nadal mieszkają w Banacie. Strona tytułowa pozycji głosi, że spełnia ona wszelkie wymogi Ministerstwa Oświaty, Młodzieży i Nauki w Bułgarii, wymienia się także nazwiska i funkcje pełnione przez 10 recenzentów i konsultantów, co zapewne ma podnosić rangę publikacji, firmowanej nazwiskiem ministra bez teki Bożidara Dimitrowa (byłego ministra szkolnictwa, co do którego kontrowersyjnych poglądów politycznych - i nie tylko - nie sposób odnieść się w tym artykule). Członkowie Stowarzyszenia Bułgarów Banackich w Bułgarii (Дружеството на банатските българи в България) oceniają ten elementarz zupełnie inaczej, dostrzegają w nim próbę zbliżenia ich języka do oficjalnej normy i widzą zagrożenie dla banackiej tradycji językowej. Jeden z członków Stowarzyszenia, Aleksandr Lavrov, opublikował na oficjalnej stronie internetowej <http://falmis.org> obszerny artykuł, którego końcowy fragment przytaczam poniżej:

Модернизацията на банатския-български език трябва да следва от близо развитието на официалния български книжовен език и да отразява по подходящ начин неговите промени, така, че да не нараства дистанцията между двете паралелни форми, а напротив, без ущърб да намалява, когато и колкото е допустимо, защото центърът на българщината е и ще си остане в държавата България. Банатският-български език да остане официалния език на документацията на банатските български дружества извън България, на него да се води комуникацията между отделните общностни групи, да го ползват общностните медии. Всички инициативи, свързани с него, да се обсъждат широко и свободно във всички дружества и след постигане на консенсус да се им се дава право на живот. В светлината на всичко казано до тук, новопоявилият се „Буквар и Читанка” влиза в противоречие не само с интересите на днешните банатски българи, но и с принципите, оставени от прадедите ни интелектуалци и другите техни колеги, положили основите на модерната банатска-българска книжовност и култура (Лавров 2011) ${ }^{3}$.

${ }^{3}$ „Modernizowanie języka banacko-bułgarskiego powinno przebiegać z uwzględnieniem rozwoju oficjalnego bułgarskiego języka literackiego i odzwierciedlać w odpowiedni sposób zachodzące w nim zmiany, jednak powinno się to odbywać tak, by nie narastał dystans między dwiema paralelnymi normami, a przeciwnie - by ten dystans bez uszczerbku się zmniejszał, zawsze wtedy, kiedy jest to dopuszczalne i w stopniu, w jakim będzie to dopuszczalne, ponieważ jądrem bułgarszczyzny jest i zawsze będzie państwo Bułgaria. Język banacko-bułgarski powinien pozostać oficjalnym językiem dokumentacji dla stowarzyszeń Bułgarów banackich żyjących na obczyźnie, powinna być w nim prowadzona komunikacja między poszczególnymi grupami, powinny go wykorzystywać ich media. Warto, by wszelkie inicjatywy z nim związane były szeroko i swobodnie dyskutowane na forum wszystkich stowarzyszeń, tak, by w ich rezultacie ustalonego konsensu mogły wejść w życie. W świetle 
Tego typu wypowiedzi, najczęściej utrzymanych w znacznie ostrzejszym tonie, można znaleźć w Internecie bez liku. Wydaje się więc, że współcześni Bułgarzy banaccy, mimo funkcjonowania odpowiednich ustaw i innych przepisów prawnych gwarantujących im nie tylko prawo do swobody wyznania, ale także do zachowania własnego języka, zaczęli odczuwać realne zagrożenie i wydanie tej książki odebrali jako próbę przymusowej unifikacji językowej z otoczeniem, co w szczególności dotyczy tych, którzy zdecydowali się na powrót z Banatu do ojczyzny.

\section{Literatura}

Vasilčin J., 1991, Biblija i Kátaćizmus za dicáta, Timišvár.

Walczak-Mikołajczakowa M., 2004, Piśmiennictwo katolickie w Bułgarii. Język utworów II połowy XVIII wieku, Poznań.

Walczak-Mikołajczakowa M., 2008, Bułgarzy banaccy i ich język, w: Religijna mozaika Bałkanów, red. M. Walczak-Mikołajczakowa, Gniezno, s. 221-229.

Walczak-Mikołajczakowa M., 2010, Migracje religijne na Bałkanach po soborze trydenckim (na przykładzie bułgarskich katolików, w: Obrazy migracji, red. K. Ilski, Poznań, s. 109-115.

Walczak-Mikołajczakowa M., 2012, Język trwałym wykładnikiem kultury Bułgarów banckich (na przykładzie najnowszego wydania katechizmu), w: Topografia tożsamości, t. 2, red. A. Firlej, W. Jóźwiak, Poznań, s. 149-159.

Асенова П., Ликоманова И., Тишева Й., Джонова М. (red.), 2007, Българските острови на Балканите, София.

Дружество на банатските българи в България, <http://falmis.org>, 10.06.2014.

Летопис на Българската францисканска провинция, Научен архив на Ииститута за история БАН, t. 1, s. 33-35.

Колев Й., 2005, Българите извън България, София.

Лавров А., 2011, Накратко: За създаването, опазването и развитието на банатския-български книжовен език, <http://falmis.org/statii/banatsi-balgari/367-nakratko-za-sazdavaneto-opazvaneto-i-razvitieto-na-banatskiya-balgarskiknizhoven-ezik>, 10.06.2014.

tego, co zostało powiedziane powyżej, należy stwierdzić, że nowy «Elementarz i czytanka» wchodzi w konflikt nie tylko z interesami współczesnych Bułgarów banackich, ale też z zasadami, które odziedziczyliśmy po pradziadach intelektualistach i ich współpracownikach, którzy stworzyli podwaliny pod rozwój współczesnego banacko-bułgarskiego piśmiennictwa i kultury" [przekład M.W.M.]. 
Милетич Л., 1896, На гости у банатските българи, „Български преглед” nr 1, s. 40-57; nr 2, s. 63-88.

Милетич Л., 1897, Заселението на католишките българи в Седмиградско и Банат, „Сборник на народни умотворения, наука и книжнина” nr 14, s. 284-543.

Милетич Л., 1900, Книжнината и езикът на банатските българи, „Сборник за народни умотворения, наука и книжнина" $\mathrm{nr} 16-17, \mathrm{s.}$ 405-481.

Младенов М., 1993, Българските говори в Румъния, София.

Нягулов Б., 1999, Банатските българи. Историята на една малцинствена общиост във времето на националните държави, София.

Стойков С., 2002, Българска диалектология, София.

Янков А., 2003, Календарните празници и обичаи на българите католиции (края на XIX-средата на XX век), София. 
